Osteomalacia should be suspected, particularly in the resistant cases. If detected it should be treated with vitamin D. Nevertheless, the dangers of vitamin-D overdose must be stressed and for this reason regular therapeutic doses of vitamin $\mathrm{D}$ should be given only with the safeguard of regular supervision.

\section{REFERENCES}

Cooke, W. T., Johnson, A. G., and Woolf, A. L. (1966). Brain, 89, 663. Cooke, W. T., and Smith, W. T. (1966). Brain, 89, 683.

Glass, G. B. J., Boyd, L. J., Gellin, G. A., and Stephanson, L. (1954). A

Knox, J. D. E., and Delamore, I. W. (1960). British Medical fournal, 2, 1494

Olivarious, B. de F., and Roos, D. (1965). Lancet, 2, 1298.

\title{
Urinary Concentrating Ability in Women with Asymptomatic Bacteriuria in Pregnancy
}

\author{
G. L. WILLIAMS,* M.B., B.CH., M.R.C.o.g.; H. CAMPBELL, $†$ M.A., M.B., F.S.S. ; K. J. DAVIES $\ddagger$
}

Summary : The incidence of impaired renal concentrat$N$ ing abitity in pregnant women with asymptomatic significant becteriuria is significantly less than previously reported when osmolality readings are performed on every urine specimen obtained during the 24 hours' deprivation of fuids. The concentrating defect is more considerable as pregnancy progresses. The lower the maximum urinary osmolality the more difficult is the treatment of the patient, and the higher the incidence of acute pyelonephritis.

\section{Introduction}

Kaitz (1961) showed that certain pregnant women with asymptomatic bacteriuria had impaired urinary concentrating ability, a finding confirmed by Norden and Tuttle (1965) and by Elder and Kass (1965). This paper further investigates the relationship of maximum urinary concentrating ability in pregnant women with bacteriuria to age, parity, period of gestation when the test is performed, osmolality readings throughout a 24-hour period of restricted fluids, and total 24-hour urinary volume. The subsequent development of symptomatic urinary tract infection is also studied.

Throughout this study significant bacteriuria is defined as the presence of more than 100,000 Gram-negative organisms per $\mathrm{ml}$. of urine in at least two consecutive specimens in any patient.

\section{Patients and Methods}

All pregnant women who attended for antenatal care in Cardiff in 1967 had a midstream urine specimen collected on their first visit. Preliminary vulval cleansing with a weak cetrimide solution (Williams et al., 1969) was first performed. Clean voided specimens were then returned to the laboratory in iced vacuum flasks.

Urino Culture.-Within two hours of collection dilutions of urine were spread on to the surface of blood agar and MacConkey's medium plates. Quantitative colony counts were made after overnight incubation at $37^{\circ} \mathrm{C}$. If the specimen contained more than 10,000 Gram-negative organisms per ml., a second specimen was examined within 10 days.

Of 5,542 patients $211(3.8 \%)$ were found to have asymptomatic significant bacteriuria. These 211 were told that a slight

\footnotetext{
* United Cardiff Hospitals, Research Fellow in Obstetrics and Gynaecology.

† Senior Lecturer, Department of Medical Statistics.

$¥$ Department of Medical Statistics.

Weloh National School of Medicine, Cardiff.
}

urinary tract infection might be present, and arrangements were made for their admission to the antenatal ward for a period of 24 hours within the next few days. Studies were completed on $163(77 \%)$ patients. The period of the test was from 12 noon on the first day to 12 noon on the second, during which period they refrained from all fluids, dry food only being allowed. They were not kept in bed, and were asked to pass urine three- to four-hourly. All the urine passed was collected and measured. Osmolality determinations were done on the Advanced Instruments Osmometer, the urine being left at $4^{\circ} \mathrm{C}$. until the measurement was performed within three hours of collection.

Similar investigations were performed on a group of pregnant women with sterile urine. One woman at each hospital booking clinic was asked if she would come into hospital for a period of 24 hours in order that her renal function could be estimated. It was explained to her that the test would entail deprivation of fluid for 24 hours. If she preferred not to do so, another was asked, and so on until a volunteer was found. In this way 45 normal controls were included in the study.

One of the major aims of this study was to determine the effects of treatment of asymptomatic bacteriuria in pregnancy, and a randomized controlled clinical trial was started as soon as the presence of bacteriuria had been established and the osmolality studies completed. The clinical trial will be reported elsewhere, but osmolality had an important effect on the outcome of treatment which is considered here.

Patients were allocated at random to "treatment" or "control" groups. The treatment group was prescribed a course of sulphadimidine $1 \mathrm{~g}$. three times a day for seven days, then two or three weeks after the end of this course the urine was re-examined. If it was sterile no further treatment was given, if it was not sterile the patient was prescribed $100 \mathrm{mg}$. of nitrofurantoin twice daily for seven days. If this was successful no further treatment was given, but if the bacteriuria still persisted ampicillin $250 \mathrm{mg}$. three times daily for seven days was prescribed ; if necessary this course of ampicillin was repeated. No patient in the treatment group received more than one course of sulphadimidine or of nitrofurantoin, but some required repeated courses of ampicillin. Those patients who relapsed after having sterile urine continued the pattern of these treatments at the point where it had been interrupted.

Patients allocated to the contrast group did not receive treatment for their asymptomatic bacteriuria until such time as symptoms presented. These women were, however, given a supply of sulphadimidine and told to take $1 \mathrm{~g}$. three times a day for seven days if they suffered from symptoms of frequency, 
dysuria, fever, or loin pain ; they were also asked then to inform their own doctor or the antenatal clinic, whichever was more convenient.

During the course of the pregnancy and for the first 10 days of the puerperium all cases of acute pyelonephritis, defined as loin pain with tenderness and/or fever, were recorded.

\section{Results}

\section{Comparability of the Groups}

Three groups were studied: group A, 163 pregnant women with asymptomatic bacteriuria who had completed their investigations before the 30th week of pregnancy ; group B, 45 pregnant women with sterile urine; and group C, 20 nonpregnant final-year medical students. Patients were selected by the fact that they were prepared to enter hospital for 24 hours for the study. In other respects there is no sign of bias in their selection.

Comparability of groups A, B, and C by age, parity, volume of urine collected, and week when test was performed is shown in Table I. Variations in the social class distribution could be ascribed to chance.

There was no significant difference between the groups except for the week of pregnancy in which the test was made. On average the tests on group A were made 11 days later. A correcting factor was considered to standardize this difference, but as the women with sterile urine did not show a significant correlation between maximum osmolality and duration of pregnancy at the time of the test this was not in fact used.

It was a most difficult task to select and persuade a group of healthy non-pregnant women of comparable age, parity, and social class to enter hospital for these tests. Group C, therefore, though not comparable with the other two groups, does give some indication of the osmolality of urine among young healthy non-pregnant women.

\section{Urine Osmolality During 24-hour Test}

During the course of the 24-hour test, when no fluids were allowed to be drunk, the number of samples of urine obtained varied for each woman, but in only four cases was a sample not provided at some time between 6 p.m. and midnight and all women provided at least one sample in one of the periods between 6 a.m. and noon.

Table II shows the maximum urine osmolalities in the three groups. In women with bacteriuria (group A) $31 \%$ were unable to concentrate above $750 \mathrm{mOsm} / \mathrm{kg}$., in the group with sterile urine (group B) all concentrated above $750 \mathrm{mOsm} / \mathrm{kg}$., and in the non-pregnant women (group C) concentrations were all above $850 \mathrm{mOsm} / \mathrm{kg}$.

Table III shows the time of day when maximum urine osmolality was achieved: $63 \%$ of group A, $76 \%$ of group B, and $75 \%$ of group $\mathrm{C}$ achieved their maximum in the final sixhour period between $6 \mathrm{a} . \mathrm{m}$. and 12 noon. This difference is not statistically significant, therefore the use of this criterion is not an important one to discriminate women with defective concentrating power.
TABLE II.-Maximum Urine Osmolality. Frequency Distribution

\begin{tabular}{|c|c|c|c|c|c|c|c|}
\hline \multirow{2}{*}{\multicolumn{2}{|c|}{$\begin{array}{c}\text { Urine } \\
\text { Osmolality } \\
(\mathrm{mOsm} / \mathbf{k g})\end{array}$}} & \multicolumn{2}{|c|}{ Group A } & \multicolumn{2}{|c|}{ Group B } & \multicolumn{2}{|c|}{ Group C } \\
\hline & & No. & $\%$ & No. & $\%$ & No. & $\%$ \\
\hline $\begin{array}{r}<750 \\
750-849 \\
850-999 \\
1,000+\end{array}$ & $\begin{array}{l}\cdots \\
\ddot{0}\end{array}$ & $\begin{array}{l}50 \\
38 \\
58 \\
17\end{array}$ & $\begin{array}{l}31 \\
23 \\
36 \\
10\end{array}$ & $\begin{array}{l}\overline{10} \\
25 \\
10\end{array}$ & $\left.\begin{array}{l}22- \\
56 \\
22\end{array}\right\} 78$ & $\begin{array}{r}\overline{5} \\
15\end{array}$ & $\left.\begin{array}{c}\text { - } \\
75\end{array}\right\} 100$ \\
\hline Total & $\ldots$ & 163 & 100 & 45 & 100 & 20 & 100 \\
\hline \multicolumn{2}{|c|}{$\begin{array}{l}\text { Mean maximum urine } \\
\text { osmolality }{ }^{*} \\
\text { Standard deviation }\end{array}$} & \multicolumn{2}{|r|}{$\begin{array}{l}823 \\
145\end{array}$} & \multicolumn{2}{|c|}{$\begin{array}{r}930 \\
95\end{array}$} & \multicolumn{2}{|c|}{$\begin{array}{r}1,052 \\
92\end{array}$} \\
\hline
\end{tabular}

Difference between the means is significant at the $1 \%$ level.

TABLE III.-Time of Day when Maximum Osmolality was Achieved

\begin{tabular}{|c|c|c|c|c|c|c|}
\hline \multirow{2}{*}{ Time } & \multicolumn{2}{|c|}{ Group A } & \multicolumn{2}{|c|}{ Group B } & \multicolumn{2}{|c|}{ Group C } \\
\hline & No. & $\%$ & No. & $\%$ & No. & $\%$ \\
\hline $\begin{array}{l}12 \text { noon }-6 \text { p.m. } \\
6 \text { p.m. }-12 \text { midnight } \\
12 \text { midnight }-6 \text { a.m. } \\
6-9 \text { a.m. } \\
9 \text { a.m. }-12 \text { noon .. }\end{array}$ & $\begin{array}{l}6 \\
41 \\
14 \\
37 \\
65\end{array}$ & \begin{tabular}{c|c}
4 & \\
25 & \\
9 & \\
23 & 63 \\
40 & 63
\end{tabular} & $\begin{array}{r}4 \\
6 \\
1 \\
21 \\
13\end{array}$ & $\begin{array}{c}9 \\
13 \\
2 \\
27 \\
47 \\
29\end{array} \quad 76$ & $\frac{\overline{5}}{5}$ & $\left.\begin{array}{l}25- \\
25 \\
50\end{array}\right\} 75$ \\
\hline & 163 & 100 & 45 & 100 & 20 & 100 \\
\hline
\end{tabular}

Fig. 1 shows the mean osmolality readings ( \pm 2 standard error) at three-hour periods in the 163 pregnant women with bacteriuria and the 45 pregnant women with sterile urine. It

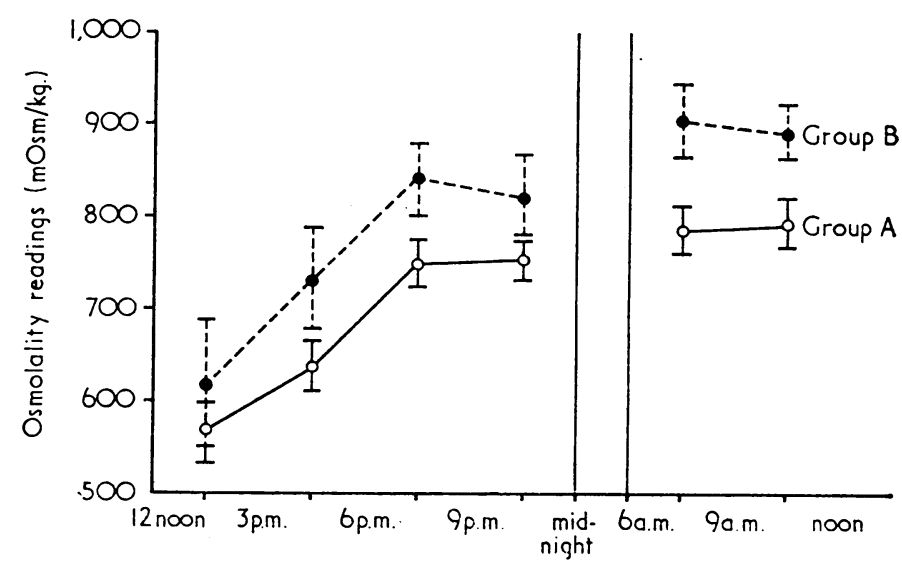

FIG. 1.-Mean osmolality readings ( +2 S.E.) at three-hour periods Group A, 163 women with bacteriuria. Group B, 45 women with sterile urine.

shows that women with bacteriuria have consistently and significantly lower values. At the lowest level during the 24-hour period, which in both series is between 12 noon and 3 p.m., which is the start of the test, the series are not significantly different, but at all other points of time the difference is marked. The greatest divergence in this series was during the period 6 to 9 a.m., when the readings in the group with bacteriuria were, on average, 116 lower. Thus the pregnant women with bacteriuria failed to concentrate the urine during the morning peak after a fast from fluids of 18 hours. There were a few women who passed urine during the time midnight to 6 a.m., but these were a selected group and the mean values for these readings are excluded from Fig. 1.

\begin{tabular}{|c|c|c|c|c|c|c|c|c|}
\hline & & & & $\begin{array}{c}\text { Group A. } \\
\text { Pregnant Women } \\
\text { with Bacteriuria. } \\
\text { Mean } \pm \text { S.E. }\end{array}$ & $\begin{array}{c}\text { Group B. } \\
\text { Pregnant Women } \\
\text { with Sterile Urine. } \\
\text { Mean } \pm \text { S.E. }\end{array}$ & $\begin{array}{c}\text { Group C. } \\
\text { Non-pregnant } \\
\text { Women } \\
\text { Mean } \pm \text { S.E. }\end{array}$ & $\begin{array}{c}\text { Difference } \\
\text { Between Groups } \\
\text { A and B. } \\
\text { Means } \pm \text { S.E. }\end{array}$ & Significance \\
\hline $\begin{array}{l}\text { No. of cases } \\
\text { Age } . . \\
\text { Parity } \\
\text { Volume } \\
\text { Week of test }\end{array}$ & $\begin{array}{l}\because \\
\because \\
\because\end{array}$ & $\begin{array}{l}\because \\
\because \\
\because\end{array}$ & $\begin{array}{l}\because \\
\because \\
\cdots\end{array}$ & $\begin{array}{r}163 \\
24 \cdot 816 \pm 0 \cdot 487 \\
2 \cdot 245 \pm 0 \cdot 144 \\
794 \pm 19 \\
20 \cdot 779 \pm 0 \cdot 454\end{array}$ & $\begin{array}{c}45 \\
25 \cdot 622 \pm 0.859 \\
2 \cdot 267 \pm 0.214 \\
758 \pm 33 \\
19 \cdot 200 \pm 0.681\end{array}$ & $\begin{array}{c}20 \\
22 \cdot 15 \pm 0 \cdot 22 \\
699 \pm 42\end{array}$ & $\begin{array}{r}-0.806 \pm 0.987 \\
-0.022 \pm 0.258 \\
+36 \pm 38.5 \\
+1.579 \pm 0.818\end{array}$ & $\begin{array}{l}t=-0.82 \text { N.S. } \\
t=-0.09 \text { N.S. } \\
t=+0.94 \text { N.S. } \\
t=+1.93\end{array}$ \\
\hline
\end{tabular}




\section{Correlation with Other Factors}

It seemed possible that the maximum osmolality of urine during the 24-hour test might be affected by the age and parity of the mother or by the total 24-hour urine volume and the week of pregnancy when test was performed. Correlation coefficients between the maximum osmolality and each of these factors are shown in Table IV for both group A and group B.

TABle IV.-Maximum Urine Osmolality Values Correlated with Age, Parity, 24-Hour Urine Volume, and Week of Test

\begin{tabular}{|c|c|c|c|c|}
\hline & \multicolumn{2}{|c|}{ Group $A(N=163)$} & \multicolumn{2}{|c|}{ Group $B(N=45)$} \\
\hline & $\begin{array}{l}\text { Correlation } \\
\text { Coefficient }\end{array}$ & $\begin{array}{c}\text { Statistical } \\
\text { Significance }\end{array}$ & $\begin{array}{l}\text { Correlation } \\
\text { Coefficient }\end{array}$ & $\begin{array}{c}\text { Statistical } \\
\text { Significance }\end{array}$ \\
\hline $\begin{array}{lll}\text { Age } & . & \\
\text { Parity } & \cdots & \\
\text { Total 24-hour urine }\end{array}$ & $\begin{array}{l}-0.077 \\
-0.138 \\
-0.260\end{array}$ & $\begin{array}{l}\text { Not significant } \\
\text { Not significant } \\
\text { Significant at } \\
\text { a o teyel }\end{array}$ & $\begin{array}{l}+0.088 \\
+0.167 \\
-0.281\end{array}$ & $\begin{array}{l}\text { Not significant } \\
\text { Not significant } \\
P=0.07\end{array}$ \\
\hline Week & -0.234 & $\begin{array}{l}\text { Significant at } \\
1 \% \text { level }\end{array}$ & $+0 \cdot 132$ & Not significan \\
\hline
\end{tabular}

There was no significant correlation with age or with parity within either group.

The correlations between maximum osmolality and 24-hour urine volume are similar in both series. Although the coefficient for group B does not quite reach the $5 \%$ significance level, it is high enough to suggest a significant relationship on a larger number of readings. Both correlations are negative, which means that osmolality is lower in women who pass a larger volume of urine. The similarity of the correlations suggests that the presence of bacteria in the renal parenchyma does not effectively alter the relationship between maximum osmolality readings and total 24 -hour urine volume.

The duration of pregnancy at the time of the osmolality test does, however, appear to be important. In group B no statistically significant relationship could be shown between maximum urine osmolality and the week of gestation when the test was performed. The mean of the urine osmolality in those women in group B who were examined later in pregnancy was higher than in those women examined earlier, but the difference was not significant. Group A shows a very significant negative correlation between osmolality and duration of pregnancy $(\mathbf{r}=-0.234)$. As pregnancy progresses from 12 to 30 weeks, the period here studied, the maximum osmolality of urine falls from a mean value of 875 at 12 weeks to a mean value of 769 at 30 weeks. The regression lines for the two groups (Fig. 2) clearly indicate the divergence between the two groups. Early in pregnancy there was no significant difference between the maximum osmolality found in women with bacteriuria and that found in women with sterile urine, but as pregnancy progresses the difference becomes marked. These findings suggest that from the 12th to the 30th week of pregnancy the presence of bacteria in the medullary tissue significantly reduces the ability of the tubules to concentrate urine. When the urine is sterile, the renal concentrating power during this same period remains constant.

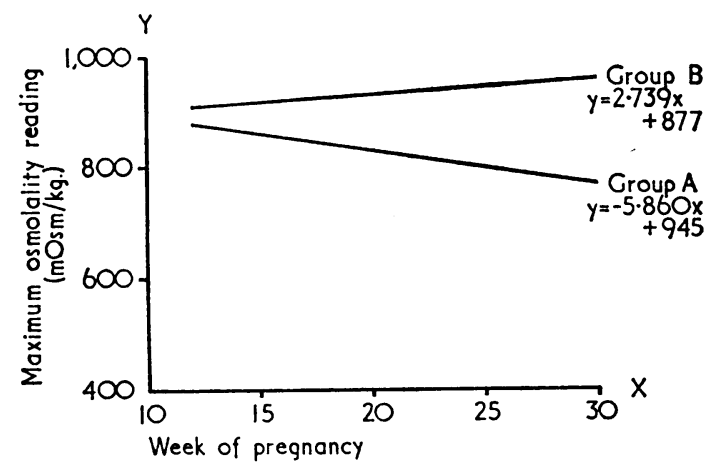

FrG. 2.-Regression of maximum osmolality reading on week of pregnancy.

\section{Effect of Treatment on Concentrating Ability}

All patients who booked before the 30th week of pregnancy were allocated at random to a treatment or control group. Subsequent analysis was restricted to patients with coliform bacteriuria of whom, after certain exclusions, 85 were treated and 78 were contrast patients. The total number of 163 is coincidental; the group is not exactly similar to the group of 163 in the previous section, though 127 patients were common to both groups.

\section{Incidence of Acute Pyelonephritis}

Table $\mathrm{V}$ shows the incidence of acute pyelonephritis, defined as loin pain and tenderness with or without fever at three broad arbitrary levels of osmolality. In antenatal patients there was no record of raised temperature, but all postnatal patients had

TABLE V.-Maximum Urine Osmolality and the Incidence of Acute Pyelonephritis, Distinguishing Treated and Control Groups

\begin{tabular}{|c|c|c|c|c|c|c|c|c|c|}
\hline \multirow{3}{*}{$\begin{array}{c}\text { Urine } \\
\text { Osmolality } \\
\text { (mOsm } / \mathrm{kg} .)\end{array}$} & \multicolumn{3}{|c|}{ Treated Group } & \multicolumn{3}{|c|}{ Control Group } & \multicolumn{3}{|c|}{ Total } \\
\hline & \multirow{2}{*}{ No. } & \multicolumn{2}{|c|}{$\begin{array}{c}\text { Acute Pyelo- } \\
\text { nephritis }\end{array}$} & \multirow{2}{*}{ No. } & \multicolumn{2}{|c|}{$\begin{array}{c}\text { Acute Pyelo- } \\
\text { nephritis }\end{array}$} & \multirow{2}{*}{ No. } & \multicolumn{2}{|c|}{$\begin{array}{l}\text { Acute Pyelo- } \\
\text { nephritis }\end{array}$} \\
\hline & & No. & $\%$ & & No. & $\%$ & & No. & $\%$ \\
\hline $\begin{array}{c}<750 \\
750-849 \\
850+\end{array}$ & $\begin{array}{l}25 \\
22 \\
38\end{array}$ & $\begin{array}{l}3 \\
2 \\
0\end{array}$ & $\begin{array}{r}12 \\
9 \\
0\end{array}$ & $\begin{array}{l}23 \\
15 \\
40\end{array}$ & $\begin{array}{l}9 \\
4 \\
5 \\
\end{array}$ & $\begin{array}{l}39 \\
27 \\
12 \cdot 5\end{array}$ & $\begin{array}{l}48 \\
37 \\
78\end{array}$ & $\begin{array}{r}12 \\
6 \\
5\end{array}$ & $\begin{array}{r}25 \\
16 \\
6\end{array}$ \\
\hline Total .. & 85 & 5 & 6 & 78 & 18 & 23 & 163 & 23 & 14 \\
\hline
\end{tabular}

a fever of $39^{\circ} \mathrm{C}$. or greater. In both treated and contrast groups there is a higher incidence among women with low urine osmolality and a lower rate among women with better concentrating ability. Irrespective of treatment, $12(25 \%)$ of 48 patients with urine osmolality of less than $750,6(16 \%)$ of 37 with osmolality between 750 and 849 , and $5(6 \%)$ of 78 with osmolality of 850 or more developed acute pyelonephritis. The differences are significant at the $5 \%$ level of probability $\left(x^{2}=\right.$ $8.65, \mathrm{n}=2,0.02>\mathrm{P}>0.01)$. The clinical picture, which was true for all cases, remained true for the postnatal cases. Four women $(8 \%)$ suffered postnatal attacks of loin pain and pyrexia in the osmolality group less than $750 \mathrm{mOsm} / \mathrm{kg}$., two $(5 \%)$ in the group 750-849 $\mathrm{mOsm} / \mathrm{kg}$., and none in the high level group of $850 \mathrm{mOsm} / \mathrm{kg}$. or more. Hence the lower the maximum osmolality of the urine, the greater was the risk of developing acute pyelonephritis.

\section{Maximum Osmolality and Response to Treatment}

The relationship between the maximum urine osmolality and the vigour of the treatment required to clear the urine of bacteria is shown in Table VI. Of the 85 patients in the treatment group $39(46 \%)$ were cleared of infection by sulphadimidine alone, which was the first course of treatment. In women with osmolality of less than 750 , however, only $24 \%$ could be cleared by sulphadimidine, whereas $63 \%$ of women were cured who had an osmolality of 850 or greater. A corollary of this

TABLE VI.-Maximum Urine Osmolality Related to Antenatal Treatment

\begin{tabular}{|c|c|c|c|c|c|c|c|c|c|c|}
\hline \multirow{3}{*}{$\begin{array}{c}\text { Urine } \\
\text { Osmo- } \\
\text { lality } \\
\text { (mOsm/ } \\
\text { kg.) }\end{array}$} & \multicolumn{8}{|c|}{ Antenatal Treatment } & & \\
\hline & \multicolumn{2}{|c|}{$\begin{array}{l}\text { Sulpha- } \\
\text { dimidine }\end{array}$} & \multicolumn{2}{|c|}{$\begin{array}{c}\text { Sulpha- } \\
\text { dimidine+ } \\
\text { Nitro- } \\
\text { furantoin }\end{array}$} & \multicolumn{2}{|c|}{$\begin{array}{l}\text { Sulpha- } \\
\text { dimidine }+ \\
\text { Nitro- } \\
\text { furantoin }+ \\
\text { Ampicillin }\end{array}$} & \multicolumn{2}{|c|}{ Other } & \multicolumn{2}{|c|}{ Total } \\
\hline & No. & $\%$ & No. & $\%$ & No. & $\%$ & No. & $\%$ & No. & $\%$ \\
\hline $\begin{array}{r}<750 \\
750-849 \\
850+ \\
\end{array}$ & $\begin{array}{r}6 \\
9 \\
24 \\
\end{array}$ & $\begin{array}{l}24 \\
41 \\
63 \\
\end{array}$ & $\begin{array}{l}5 \\
5 \\
5 \\
\end{array}$ & $\begin{array}{l}20 \\
23 \\
13 \\
\end{array}$ & $\begin{array}{r}12 \\
8 \\
8 \\
\end{array}$ & $\begin{array}{l}48 \\
36 \\
21 \\
\end{array}$ & $\frac{2 *}{1+}$ & $\frac{8}{3}$ & $\begin{array}{l}25 \\
22 \\
38 \\
\end{array}$ & $\begin{array}{l}100 \\
100 \\
100 \\
\end{array}$ \\
\hline Total & 39 & 46 & 15 & 18 & 28 & 33 & 3 & 3 & 85 & 100 \\
\hline
\end{tabular}


experience is that a greater proportion of women with low osmolality required nitrofurantoin or ampicillin to eradicate bacteriuria. Forty-three women who were not successfully treated by sulphadimidine were then treated by nitrofurantoin. Of these, $15(35 \%)$ were cleared, but of the 17 whose urine osmolality was below $750 \mathrm{mOsm} / \mathrm{kg}$. only $5(29 \%)$ were cleared. It is apparent, therefore, that the lower the maximum osmolality the more difficult it was to eradicate the bacteriuria.

This same problem was further examined in a slightly different way in Table VII, which shows the mean value of

TABle VII.-Mean Maximum Antenatal Urine Osmolality Related to

\begin{tabular}{|c|c|c|c|c|c|}
\hline \multicolumn{3}{|c|}{ Treated Group } & \multicolumn{3}{|c|}{ Control Group } \\
\hline & No. & Mean \pm S.D. & & No. & Mean \pm S.D. \\
\hline $\begin{array}{l}\text { Sulphadimidine } \\
\text { Sulphadimidine }+ \\
\text { nitrofurantoin } \\
\text { Sulphadimidine }+ \\
\text { nitrofurantoin }+ \\
\text { ampicillin .. }\end{array}$ & $\begin{array}{l}39 \\
15 \\
28\end{array}$ & $\begin{array}{l}873 \pm 135 \\
797 \pm 85 \\
760 \pm 161\end{array}$ & $\begin{array}{l}\text { Untreated } \\
\text { Treated }\end{array}$ & $\begin{array}{l}56 \\
22\end{array}$ & $\begin{array}{l}859 \pm 135 \\
775 \pm 175\end{array}$ \\
\hline & 82 & & & 78 & \\
\hline
\end{tabular}

the maximum urine osmolality for those groups of patients who required the various stages of treatment and also the mean values for the contrast patient.

The lowest mean value was for patients who required ampicillin. The difference between the treatment means was significant $(F=5 \cdot 8)$; that between the untreated and treated control groups reached significance $(t=2.0 ; \mathrm{P}=0.05)$.

\section{Discussion}

Kaitz (1961) investigated 20 pregnant women with asymptomatic bacteriuria at varying periods of gestation. The investigations were carried out on outpatients, who were asked to refrain from all fluids for 24 hours. At the end of the 24 hours a urine specimen was collected and the osmolality of this specimen was determined. He found that 9 of the 20 women had urinary osmolality below $700 \mathrm{mOsm} / \mathrm{kg}$. and 11 had urinary osmolality below $750 \mathrm{mOsm} / \mathrm{kg}$.

Norden and Tuttle (1965) investigated 24 pregnant women with asymptomatic bacteriuria whose period of gestation varied from 18 to 38 weeks. Each patient was instructed not to drink any liquid for 24 hours before the test. A first morning specimen and a clean voided specimen within the following three hours were obtained from each subject. Ten of the 24 women were unable to concentrate their urine above $700 \mathrm{mOsm} / \mathrm{kg}$. The defect was reversible, with eradication of the bacteriuria by chemotherapy.

Elder and Kass (1965) studied 71 pregnant patients with asymptomatic bacteriuria. They were instructed to abstain from all forms of liquid for the 18 hours before their clinic visit, and the osmolality of the urine specimen then obtained was determined. Of the women with bacteriuria $51 \%$ had a maximum osmolality of less than $700 \mathrm{mOsm} / \mathrm{kg}$., while only $18 \%$ of the women with sterile urine had values below this. They found a distinct but not statistically significant tendency for those with diminished concentrating ability to develop symptomatic disease.

The average total osmotic load to be excreted by the kidney is dependent on four main factors: the state of metabolism, dietary intake, the activities of the individual, and to some extent the physical environment. So that these factors were uniform all patients in this study were admitted to the antenatal wards for the period of the test. Osmolality estimations were performed on each specimen of urine passed during the 24 hours. Only $40 \%$ of patients with bacteriuria achieved their maximum urine osmolality during the final three hours of the test; a further $23 \%$ achieved their maximum osmolality during the penultimate three hours; $29 \%$ of the patients achieved their maximum urine osmolality during the first 12 hours of the test. Miles et al. (1954) investigated maximum urine osmolality in 13 patients with normal kidney function. They also found fluctuations in urine osmolality during progressive dehydration. It is clear, therefore, that a single urine osmolality estimation taken at the end of 24 hours' dehydration is not an adequate index of renal concentrating power, and that it is necessary to determine the osmolality of all urine specimens passed during the 24 hours and to use the maximum osmolality measured at any time as a measure of renal concentrating power.

In the present study only $29(18 \%)$ of the 163 patients were unable to concentrate their urine above $700 \mathrm{mOsm} / \mathrm{kg}$. This incidence is significantly less than that found by Kaitz (1961), by Norden and Tuttle (1965), and by Elder and Kass (1965). All our patients with sterile urine were able to concentrate above $750 \mathrm{mOsm} / \mathrm{kg}$., and this figure seems to be a more accurate index than $700 \mathrm{mOsm} / \mathrm{kg}$. Of the 163 patients 50 $(31 \%)$ were unable to achieve a maximum urine osmolality above $750 \mathrm{mOsm} / \mathrm{kg}$.

Pregnant women with significant bacteriuria have been found to have consistently and significantly lower maximum urine osmolality results throughout the 24 -hour period.

This study has shown that the stage of pregnancy when the test is performed is important. In patients with asymptomatic bacteriuria the maximum urine osmolality falls as pregnancy progresses, but in women with sterile urine it does not. Hence a compromise must be reached. To treat effectively the bacteriuria and so prevent the development of acute pyelonephritis demands an early start to therapy, whereas to test whether renal concentrating power has been damaged requires a possible delay until the fourth or fifth month of pregnancy.

Patients with impaired maximum urine osmolality are more likely to develop acute pyelonephritis either antenatally or in the puerperium, and it appears that even the development of acute pyelonephritis postnatally is dependent on impaired maximum urine osmolality antenatally.

In conclusion, the lower the maximum urine osmolality the more difficult it is to eradicate the bacteriuria ; in the control group the mean maximum urine osmolality is less in those who ultimately develop a urinary tract infection compared with those who do not. Determination of maximum urinary osmolality by the method described is a useful index to determine which of those patients with asymptomatic bacteriuria are likely to develop symptomatic urinary infection and require the more vigorous form of treatment.

We thank Professor A. C. Turnbull and the consultant obstetricians at the Maternity Hospital and St. David's Hospital, Cardiff, for allowing us to study patients under their care. We also thank Dr. R. A. Holman and Mr. J. Farrar, department of bacteriology, Welsh National School of Medicine, and Dr. D. M. D. Evans and Mr. T. Fitzgerald, department of bacteriology, St. David's Hospital, and the sisters and nursing staff. This work was made possible by a United Cardiff Hospitals research fellowship in obstetrics and gynaecology to one of us (G. L.W.).

\section{REFERENCES}

Elder, H. A., and Kass, E. H. (1965). In Progress in Pyelonephritis, edited by Edward H. Kass, p. 81. Philadelphia, Davis.

Kaitz, A. L. (1961). Fournal of Clinical Investigation, 40, 1331.

Miles, B. E., Paton, A., and de Wardener, H. E. (1954). British Medical Fournal, 2, 901 .

Norden, C. 'W., and Tuttle, E. P. (1965). In Progress in Pyelonephritis, edited by Edward H. Kass, p. 73. Philadelphia, Davis.

Williams, G. L., Campbell, H., and Davies, K. J. (1969). Fournal of Obstetrics and Gynaecology of the British Commonwealth, 76, 229. 